\title{
ARSPIVOT, A SENSOR-BASED DECISION SUPPORT SOFTWARE FOR VARIABLE-RATE IRRIGATION CENTER PIVOT SYSTEMS: PART B. APPLICATION
}

\author{
M. A. Andrade, S. A. O’Shaughnessy, S. R. Evett
}

Beyond 2020,

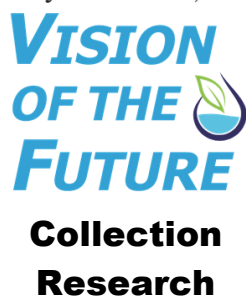

\section{HighLIGHTS}

- The ARSPivot software facilitates variable-rate irrigation management of a center pivot irrigation system.

- The software embodies a system capable of generating site-specific prescription maps based on weather, plant, and soil water information.

- ARSPivot's graphical user interface (GUI) incorporates easy-to-use geographic information system (GIS) tools that help its users to make irrigation management decisions.

\begin{abstract}
The ARSPivot software was developed for the seamless operation of a complex network consisting of a variablerate irrigation (VRI) center pivot system and an Irrigation Scheduling Supervisory Control and Data Acquisition (ISSCADA) system that interfaces with weather, plant, and soil water sensing systems. ARSPivot's graphical user interface (GUI) incorporates a built-in geographic information system (GIS) that maps a center pivot system and facilitates the analysis of data relevant to its operation. The GIS was developed following a minimalistic approach with the objective of making its geospatial data analysis tools accessible to a wide range of users (farmers, irrigation consultants, and researchers). The post-harvest analyses of two experiments carried out in the Texas High Plains during the summers of 2016 and 2017 using a three-span VRI center pivot are presented to illustrate the advantages of using ARSPivot as a decision support tool and how its GIS tools help its users make better informed decisions regarding irrigation management. In these experiments, the north-northwest (NNW) portion of a field planted with corn (Zea mays L.) was irrigated using VRI zone control, and the south-southeast (SSE) portion was irrigated using VRI speed control. Experimental plots in the NNW portion were assigned one of three irrigation levels $(80 \%, 50 \%$, or $30 \%$ replenishment of soil water depletion to field capacity in the top $1.5 \mathrm{~m})$, and their irrigation was scheduled using either a plant stress-based algorithm implemented in the ARSPivot software or manual weekly neutron probe (NP) readings. Plots in the SSE portion were assigned a single irrigation level of $80 \%$, and their irrigation was scheduled using either the plant stress method or a two-step hybrid approach in which soil water sensing was combined with the plant stress method to determine irrigation depths. Soil water sensing data for the ISSCADA system were provided by NP readings during the 2016 season and by sets of time-domain reflectometers (TDRs) installed at depths of 15, 30, and $45 \mathrm{~cm}$ during the 2017 season. No significant differences were found during either season in terms of mean dry grain yield and crop water productivity (CWP) obtained from plots irrigated at the $80 \%$ level in both sides of the field, regardless of the irrigation scheduling method or the type of VRI application method used for irrigation. No significant differences were found during either season between mean dry grain yield and CWP of plots in the NNW portion irrigated using the plant stress-based method and NP readings at the 80\% irrigation level. The lack of significant differences documented the potential of the ARSPivot system as a plant and soil water sensing-based decision support software for sitespecific irrigation management of corn using a VRI center pivot system.
\end{abstract}

\footnotetext{
(c) $(9)$ The authors have paid for open access for this article. This work is licensed under a Creative Commons AttributionNonCommercial-NoDerivatives 4.0 International License https://creative commons.org/licenses/by-nc-nd/4.0/

Submitted for review in January 2020 as manuscript number NRES 13908; approved for publication as a Research Article and as part of the National Irrigation Symposium 2020 Collection by the Natural Resources \& Environmental Systems Community of ASABE in June 2020.

Mention of company or trade names is for description only and does not imply endorsement by the USDA. The USDA is an equal opportunity provider and employer.

The authors are Manuel A. Andrade, Assistant Professor, Department of Agriculture, Veterinary, and Rangeland Science, University of Nevada, Reno, Nevada; Susan A. O'Shaughnessy, Research Agricultural Engineer, and Steven R. Evett, Research Soil Scientist, USDA-ARS Conservation and Production Research Laboratory, Bushland, Texas. Corresponding author: Susan A. O’Shaughnessy, P.O. Drawer 10, Bushland, TX 790120010; phone: 806-356-5770; e-mail: susan.oshaughnessy@usda.gov.
}

Keywords. Center pivot irrigation, Decision support system, Geographic information system, Precision agriculture, Software.

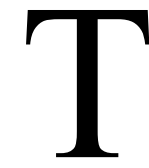
he integration of site-specific irrigation scheduling methods into the operation of center pivot irrigation systems equipped for variable-rate irrigation (VRI) lays the foundation for comprehensive management of the irrigation water applied by these systems. Scientists with the USDA-ARS developed a software that facilitates the combined operation of a VRI center pivot system and an Irrigation Scheduling Supervisory Control and Data Acquisition (ISSCADA) system (Evett et al., 2014a) 
capable of generating site-specific prescription maps by applying algorithms to data that the system gathers from plant, soil water, and weather sensing subsystems. The software, named ARSPivot, consists of a client program and a server program running simultaneously and interacting through a client-server architecture (Andrade et al., 2020). The client's main task is to maintain continuous communication with sensor network systems and irrigation machinery, and the server's main task is to provide users with a friendly graphical user interface (GUI) that facilitates the operation of a coupled ISSCADA VRI center pivot system (referred heretofore as an ISSCADA center pivot system). The GUI of the server program was developed as a simple geographic information system (GIS) software that assists in the analysis and presentation of geospatial information relevant to the management of an ISSCADA center pivot system.

At the farm level, GIS software has been used to assist multiple precision farming practices, such as site-specific management of fertilizers (Blackmer and White, 1998; Nahry et al., 2011; Peralta et al., 2015) and herbicides (Al-Gaadi and Ayers, 1999; Gerhards et al., 2002; Backes and Plümer, 2003), analysis of yield variability (Zhang et al., 1999; Bakhsh et al., 2000; Neményi et al., 2003), monitoring of soil erosion (Ramos et al., 2007), and delineation of management zones (Zhang and Taylor, 2001; Seelan et al., 2003). Management zones may be delineated according to soil property differences and topographic differences, as illustrated by Evett et al. (2014b) or for other purposes such as different crops or cropping seasons under one center pivot. General-purpose GIS software, such as ArcGIS (2020) and QGIS (2020), have also been applied to assist the site-specific management of irrigation at the farm level (Evans et al., 1996; Meron et al., 2010; Thorp and Bronson, 2013; Barker et al., 2018). Although researchers and irrigation consultants may be familiar with general-purpose GIS software, the numerous features, tools, and options implemented in this type of software limit its accessibility for farmers.

A simple GIS software incorporating site-specific irrigation management tools can encourage the adoption of precision irrigation by making the spatial analysis and presentation of information pertinent to site-specific crop water needs accessible to a wide range of users. An accompanying article (Andrade et al., 2020) describes the development of the ARSPivot software, how it allows seamless integration of the ISSCADA system into the operation of VRI center pivots, and how its server program combines basic GIS tools and irrigation scheduling methods to generate site-specific prescription maps that users can easily visualize and modify through its GUI.

In this study, we had three objectives. The first objective was to demonstrate the use of ARSPivot as a decision support software that enables the integration of canopy temperature and soil water sensor feedback for site-specific irrigation management of corn using center pivot irrigation systems equipped for either VRI speed control or VRI zone control. The second objective was to compare a site-specific irrigation scheduling method based on the combined use of soil water sensing data and canopy temperature data (called the hybrid method) against methods based on sensor feed- back from only soil water sensing or from only canopy temperature sensing. The third objective was to demonstrate the benefits of some advanced capabilities of the ARSPivot software, beyond those described by Andrade et al. (2020), by detailing the functionality of generating maps that overlay multiple layers of geospatial data pertinent to the site-specific irrigation management of VRI center pivot irrigation systems. Analyses of these maps included in this article illustrate how ARSPivot can help its users to make better informed decisions regarding the management of ISSCADA center pivot systems.

\section{MeTHODOLOGY}

In the summers of 2016 and 2017, ARSPivot was used for the integrated irrigation management of an ISSCADA center pivot system operating on a field irrigated by a three-span center pivot (radial length $131 \mathrm{~m}$ ) (Valley 8000, Valmont Industries, Valley, Neb.) located near Bushland, Texas. Soil in the area irrigated by the center pivot is a Pullman clay loam with $0 \%$ to $1 \%$ slopes $(\mathrm{PuA})$ and $1 \%$ to $3 \%$ slopes $(\mathrm{PuB})$ with a field capacity and wilting points of 0.33 and $0.19 \mathrm{~m}^{3}$ $\mathrm{m}^{-3}$, respectively (Tolk, 2003a, 2003b). A study of spatial variability indicated that the soil exhibits only minor variability across distances of $>100 \mathrm{~m}$ (Evett et al., 2009). The lack of soil variability allowed randomization of treatment plot locations and assignment of management zones according to those treatments rather than according to soil properties. A midseason corn hybrid, Dupont Pioneer P1151AM, was planted on day of year (DOY) 134 (May 13, 2016) and on DOY 135 (May 15, 2017) for the first and second case studies, respectively. The center pivot was equipped with a Pro2 control panel and a commercial VRI zone control system (Valmont Industries) with 12 sprinkler zones (fig. 1). Each sprinkler zone was six drops wide, and the drops were

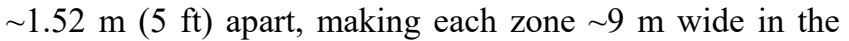
radial direction. Irrigations were applied using a low-elevation spray application (LESA) method with nozzles $\sim 46 \mathrm{~cm}$ (18 in.) above the ground. Furrows were diked to reduce runoff between plots. The ARSPivot software was executed on an embedded computer placed at the center pivot point. Microsoft Windows (ver. CE7) was used as the operating system of the embedded computer. A serial connection between the computer and the control panel using an RS232 cable allowed ARSPivot to monitor and control the center pivot.

In both years, VRI zone control was used for the northnorthwest (NNW) side of the field, which was divided into six sectors of $28^{\circ}$ each and six concentric plots with a radial width of $\sim 9 \mathrm{~m}(30 \mathrm{ft})$ each, for a total of 36 experimental plots (fig. 1). VRI speed control was used for the southsoutheast (SSE) side of the field, which was divided into eight sectors of $20^{\circ}$ each and a single concentric plot with a width of $54.9 \mathrm{~m}(180 \mathrm{ft})$, for a total of eight experimental plots (fig. 1). The resulting 44 experimental treatment plots were located within the six outermost sprinkler zones in the field and were treated as independent management zones (MZs) in the ARSPivot software (fig. 1). The two different VRI methods (zone control and speed control) were used in both years with the purpose of testing the ARSPivot software 

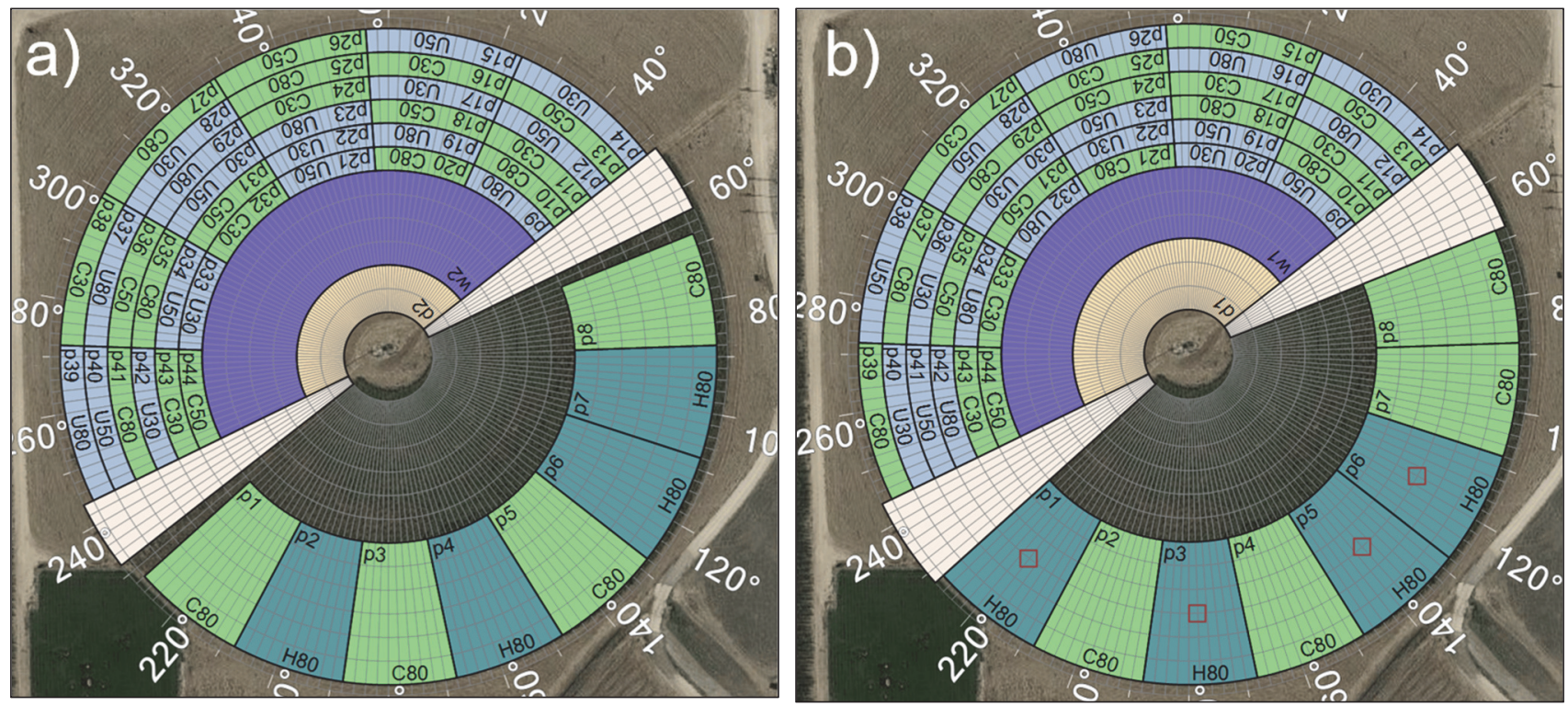

Figure 1. Experimental setups used in the (a) first (2016) and (b) second (2017) case studies as displayed in the main panel of ARSPivot's server program. Numbers inside the plots preceded by the letter $p$ indicate the numbers used to identify plots. Capital letters inside the plots indicate the irrigation scheduling method used for the plot: $\mathrm{C}=\mathrm{iCWSI}, \mathrm{U}=\mathrm{NP}$, and $\mathrm{H}=$ hybrid-NP (in 2016) or hybrid-TDR (in 2017). Numbers following the capital letters indicate the irrigation level assigned to the plot $(80 \%, 50 \%$, or $30 \%)$. The NNW and SSE sides of the field were irrigated using VRI zone control and VRI speed control, respectively, and were separated by two roads. A pair of IRTs was placed in a well-irrigated area contiguous to the experimental plots in the NNW side. Small squares inside the plots using the hybrid-TDR method (H80 in 2017 ) indicate the locations of four soil water sensing stations used during the 2017 growing season.

integration of sensor feedback with speed control commands and to compare crop response of grain yield, seasonal crop water use $\left(\mathrm{ET}_{\mathrm{c}}\right)$, and crop water productivity $(\mathrm{CWP})$ between the two VRI methods. The support of VRI speed control is one of the additional features included in the ARSPivot software with respect to an earlier version of its client program that only supported VRI zone control (O'Shaughnessy et al., 2012, 2015, 2017).

A network of 12 wireless infrared thermometers (IRTs) (SapIP-IRT, Dynamax, Houston, Tex.) was mounted on the center pivot's lateral to sense crop canopy temperatures throughout the experimental area. Two IRTs were located at the boundaries of each of the six outermost sprinkler zones and pointed inward toward the center of each sprinkler zone at oblique angles from nadir. Data collected by each pair of the two IRTs with opposing views of a sprinkler zone were averaged to estimate the canopy temperature inside the sprinkler zone, thus minimizing sun angle and IRT aiming effects (Evett et al., 2020). Two additional wireless IRTs were placed at static locations in well-irrigated areas in the NNW side of the field with opposing views of the same area. The average canopy temperature obtained by these static IRTs provided a reference canopy temperature for a wellwatered crop.

Scans of the field using the lateral-mounted IRTs were performed during both growing seasons by running the center pivot dry throughout the field so that canopy temperatures could be collected by the network of mobile IRTs mounted on the center pivot. ARSPivot incorporates a temperature scaling algorithm by Peters and Evett (2004) to estimate the crop canopy temperature at any given location and time within daylight hours using a one-time-of-day measure- ment taken at such location. ARSPivot applied this algorithm to calculate the theoretical crop water stress index (CWSI) (Jackson et al., 1981) every minute throughout daylight hours using: (1) canopy temperatures sensed with mobile IRTs, avoiding hours near sunrise and sunset per Peters and Evett (2004); (2) canopy temperatures sensed continuously by the pair of static IRTs; and (3) microclimatological data obtained from a weather station located next to the center pivot point. Sensors from Campbell Scientific (Logan, Utah) were used to measure air temperature and relative humidity (model HC2S3), solar irradiance (CS300), precipitation (TE525), and wind direction and speed (Wind Sentry 03101). Data from these sensors were averaged and stored every $1 \mathrm{~min}$ in a CR3000 datalogger and polled hourly by the embedded computer at the center pivot point.

An integrated CWSI (iCWSI) was calculated at locations in the field traversed by the center pivot within daylight hours (from 9:00 h to 19:00 $\mathrm{h}$ in this study) during a scan. The iCWSI was calculated as the sum of the theoretical CWSI values calculated at locations traversed by the center pivot every minute from 9:00 h to 19:00 h in this study. Theoretical CWSI values range from 1 for a severely water stressed crop to 0 for a well-irrigated crop; thus, an iCWSI value of 250 is comparable to a theoretical CWSI value of 0.42 multiplied by $600 \mathrm{~min}(9: 00 \mathrm{~h}$ to $19: 00 \mathrm{~h})$.

\section{NNW EXPERIMENTAL SETUP AND IRRIGATION SCHEDUling (VRI ZONE CONTROL)}

The irrigation of plots in the NNW side was triggered using either the iCWSI method described by Andrade et al. (2020) or using weekly neutron probe (NP) readings (model 503DR1.5, Instrotek, Campbell Pacific Nuclear, Concord, 
Cal.). Each plot was assigned one of three irrigation treatments designated as percentages: $80 \%, 50 \%$, or $30 \%$. For plots irrigated using the NP method, these percentages represented the levels of replenishment of soil water depletion to field capacity in the top $1.5 \mathrm{~m}$ of soil. For plots irrigated using the iCWSI irrigation scheduling method, these percentages were represented by equivalent thresholds of crop water stress sensed by IRTs.

The iCWSI thresholds used for the 2016 (table 1) and 2017 (table 2) growing seasons were selected to encompass mean seasonal iCWSI values obtained from previous studies growing corn under different irrigation levels in Bushland, Texas (Evett et al., 1996; Yazar et al., 1999; O’Shaughnessy et al., 2017). The minimum iCWSI threshold of 100 corresponded to a well-irrigated corn crop and was used by O'Shaughnessy et al. (2017) to produce corn grain yields that were not significantly different than those obtained with full irrigation controlled by the NP irrigation scheduling method. An iCWSI threshold of 100 is comparable to a theoretical CWSI value of 0.167 multiplied by $600 \mathrm{~min}$. The maximum iCWSI threshold of 300 used during the 2016 season (table 1) corresponded to a severely stressed corn crop and was comparable to a CWSI value of 0.5 multiplied by 600 . Nielsen and Gardner (1987) reported that corn irrigated at CWSI values between 0.4 and 0.6 resulted in significantly smaller grain yields than corn irrigated at CWSI values between 0.1 and 0.2 .

The six irrigation treatments resulting from the combination of two scheduling methods (iCWSI and NP) and three irrigation levels $(30 \%, 50 \%$, and $80 \%)$ were randomized with six replications of each treatment and organized using a Latin square design (fig. 1). Experimental plots in the NNW side were labeled $\mathrm{CYY}$ or $\mathrm{UYY}$ (fig. 1), where $\mathrm{C}$ and $\mathrm{U}$ identify plots irrigated with the $\mathrm{iCWSI}$ and NP irrigation scheduling methods, respectively, and $Y Y$ indicates the irrigation level assigned to each plot.

For plots irrigated using the iCWSI irrigation scheduling method during the 2016 season, the maximum irrigation depth of $25.4 \mathrm{~mm}$ (1 in.) was calculated by assuming a $2.5 \mathrm{~d}$ return period for the center pivot multiplied by daily peak water use for corn in this region $(10.2 \mathrm{~mm})$. In a previous study, O'Shaughnessy et al. (2017) used the iCWSI method with a single iCWSI threshold for irrigation scheduling of corn at three irrigation levels $(100 \%, 75 \%$, and $50 \%$ replenishment of soil water depletion to field capacity). The use of a single iCWSI threshold resulted in a binary irrigation signal (irrigate or not). A binary irrigation signal could risk yield loss due to an untimely irrigation, especially if the iCWSI value calculated for an MZ was just below the threshold for receiving an irrigation. Therefore, multiple ranges of iCWSI thresholds were introduced in 2016 to support the use of multiple irrigation depths. As a first test of this approach, a minimum (12.7 mm), medium (19.1 mm), and maximum $(25.4 \mathrm{~mm})$ irrigation depth were established based on the maximum depth that could be applied to the field without causing runoff. A unique range of iCWSI thresholds was assigned to signal the minimum, medium, and maximum irrigation depths for each irrigation level (table 1). It was expected that larger thresholds would result in less frequent irrigation signals. Because producers in the region are under constant pressure to use less water for crop production, the irrigation levels for this study were established at $80 \%, 50 \%$, and $30 \%$ soil water replenishment to field capacity using either the NP method or iCWSI thresholds and soil water depletion thresholds.

During the 2017 season, the return period for the center pivot was increased to three days to allow downtime for any repairs and field work; thus, the maximum irrigation depth for this season was $30.5 \mathrm{~mm}$ (1.2 in.). Due to results from the 2016 season presented in a subsequent discussion, we used the same range of iCWSI thresholds for all irrigation levels but different minimum, medium, and maximum irrigation depths for each irrigation level during the 2017 season (table 2). The iCWSI thresholds were the same as were applied during the 2016 season for the $80 \%$ irrigation level (table 2 ).

Table 1. Irrigation depths (mm), integrated crop water stress index (iCWSI) thresholds (dimensionless), and soil water depletion (SWDr) thresholds (dimensionless) used during the 2016 season. For plots irrigated using the iCWSI irrigation scheduling method, the same three irrigation depths (minimum, medium, and maximum) were used for all irrigation levels, but three different iCWSI thresholds were used for each irrigation level.

\begin{tabular}{|c|c|c|c|c|}
\hline $\begin{array}{l}\text { Irrigation Method } \\
\text { and Level }\end{array}$ & No Irrigation & $\begin{array}{l}\text { Minimum Depth } \\
12.7 \mathrm{~mm}(0.5 \mathrm{in} .)\end{array}$ & $\begin{array}{l}\text { Medium Depth } \\
19.1 \mathrm{~mm}(0.75 \mathrm{in} .)\end{array}$ & $\begin{array}{l}\text { Maximum Depth } \\
25.4 \mathrm{~mm}(1 \text { in. })\end{array}$ \\
\hline $\mathrm{C} 80$ & $\mathrm{iCWSI}_{x} \leq 100$ & $100<\mathrm{iCWSI}_{x} \leq 150$ & $150<\mathrm{iCWSI}_{x} \leq 250$ & $\mathrm{iCWSI}_{x}>250$ \\
\hline $\mathrm{C} 50$ & $\mathrm{iCWSI}_{x} \leq 150$ & $150<\mathrm{iCWSI}_{x} \leq 250$ & $250<\mathrm{iCWSI}_{x} \leq 300$ & $\mathrm{iCWSI}_{x}>300$ \\
\hline $\mathrm{C} 30$ & $\mathrm{iCWSI}_{x} \leq 250$ & $250<\mathrm{iCWSI}_{x} \leq 300$ & $\mathrm{iCWSI}_{x}>300$ & N/A \\
\hline $\begin{array}{l}\text { Irrigation Method } \\
\text { and Level }\end{array}$ & No Irrigation & \multicolumn{2}{|c|}{$\begin{array}{l}\text { Irrigation depth determined by iCWSI irrigation } \\
\text { scheduling method using row for C } 80 \text { treatment }\end{array}$} & $\begin{array}{l}\text { Maximum Depth, } \\
25.4 \mathrm{~mm}(1 \text { in. })\end{array}$ \\
\hline $\mathrm{H} 80$ & $\mathrm{SWD} r<0.2$ & \multicolumn{2}{|c|}{$0.2 \leq \mathrm{SWD} r \leq 0.5$} & $\mathrm{SWD} r>0.5$ \\
\hline
\end{tabular}

Table 2. Irrigation depths (mm), iCWSI thresholds (dimensionless), and SWDr thresholds (dimensionless) used during the 2017 season. For plots irrigated using the iCWSI irrigation scheduling method, three different irrigation depths were used for each irrigation level, but the same three iCWSI thresholds $(100,150$, and 250$)$ were used for all irrigation levels.

\begin{tabular}{|c|c|c|c|c|}
\hline $\begin{array}{l}\text { Irrigation Method } \\
\text { and Level }\end{array}$ & $\begin{array}{l}\text { No Irrigation } \\
\text { iCWSI }_{x} \leq 100 \\
\end{array}$ & $\begin{array}{c}\text { Minimum Depth } \\
\left(D_{\min }, \mathrm{mm}\right) \\
100<\mathrm{iCWSI}_{x} \leq 150\end{array}$ & $\begin{array}{c}\text { Medium Depth } \\
\left(D_{\text {med }}, \mathrm{mm}\right) \\
150<\mathrm{iCWSI}_{x} \leq 250\end{array}$ & $\begin{array}{c}\text { Maximum Depth } \\
\left(D_{\max }, \mathrm{mm}\right) \\
\mathrm{iCWSI}_{x}>250\end{array}$ \\
\hline $\mathrm{C} 80$ & 0 & $15.2(0.6$ in. $)$ & $20.3(0.8$ in. $)$ & 30.5 (1.2 in.) \\
\hline $\mathrm{C} 50$ & 0 & 10.3 (0.4 in.) & 12.7 (0.5 in.) & 19.1 (0.75 in.) \\
\hline C30 & 0 & $6.4(0.25$ in. $)$ & 7.6 (0.3 in.) & 12.7 (0.5 in.) \\
\hline $\begin{array}{l}\text { Irrigation Method } \\
\text { and Level }\end{array}$ & No Irrigation & \multicolumn{2}{|c|}{$\begin{array}{l}\text { Irrigation depth determined by iCWSI irrigation } \\
\text { scheduling method using row for C } 80 \text { treatment }\end{array}$} & $\begin{array}{l}\text { Maximum Depth } \\
25.4 \mathrm{~mm} \text { (1 in.) }\end{array}$ \\
\hline $\mathrm{H} 80$ & $\mathrm{SWD} r<0.15$ & \multicolumn{2}{|c|}{$0.15 \leq \mathrm{SWD} r \leq 0.5$} & $\mathrm{SWD} r>0.5$ \\
\hline
\end{tabular}


For plots irrigated using the NP irrigation scheduling method, weekly NP readings were taken in $0.2 \mathrm{~m}$ increments from 0.1 to $2.3 \mathrm{~m}$ inside of the plots in the NNW side with the largest irrigation level (80\%). Every 30 days, NP measurements were taken inside of all plots using the NP irrigation scheduling method for purposes of following crop ET. The NP was calibrated in the field using methods described by Evett (2008). Any precipitation occurring prior to irrigation was subtracted from the total amount required for the week.

\section{SSE EXPERIMENTAL SETUP AND IRRIGATION SCHEDULING (VRI SPEED CONTROL)}

Plots in the SSE side were assigned a single irrigation level of $80 \%$. Irrigation was triggered by either the iCWSI irrigation scheduling method or by a two-step hybrid method that combines soil water sensing feedback data with the $\mathrm{iC}$ WSI irrigation scheduling method, as described below. Both irrigation scheduling methods and the single treatment level were randomized, with four replications of each method (fig. 1). Experimental plots in the SSE side are labeled in figure 1 as $\mathrm{C} 80$ or $\mathrm{H} 80$, where $\mathrm{C}$ and $\mathrm{H}$ identify plots irrigated with the iCWSI and hybrid methods, respectively.

During the first step of the hybrid method, an average soil water depletion in the root zone (SWDr) is calculated from soil water sensing data and then compared against pre-established minimum and maximum thresholds selected to prevent over- and under-irrigation, respectively. The value of the maximum SWDr threshold was set at 0.5 during both seasons, based on soil water depletion fraction to avoid stress in corn, as in FAO 56 (Allen et al., 1998). The value of the minimum SWDr threshold represents a nearly full soil water profile and was set at 0.2 during the first study (table 1) and then adjusted to 0.15 for the 2017 season (table 2) based on results from the 2016 growing season. For plots irrigated using the hybrid method, the irrigation level represents an $80 \%$ level of replenishment of soil water depletion to field capacity that is maintained by scheduling irrigations based on soil water depletion (SWDr) and plant stress (iCWSI) thresholds. Additional details of the hybrid irrigation scheduling method can be found in Andrade et al. (2020).

During the 2016 season, soil water sensing data were provided by NP measurements in the top $1.5 \mathrm{~m}$ of soil that were collected near the centers of plots in the SSE side (fig. 1a). During the 2017 season, soil water sensing data were provided by four soil water sensing stations located near the centers of plots in the SSE side (fig. 1b). Each of these sensing stations consisted of three time-domain reflectometer (TDR) sensors (model 315L, Acclima, Meridian, Ida.) installed at depths of 15,30 , and $45 \mathrm{~cm}$. The surface to $50 \mathrm{~cm}$ depth profile sensed by the TDRs covered the main root zone of the crop where the majority of total soil water extraction occurs, as reported by Tolk et al. (1998) for a short-season corn grown in Pullman soil at Bushland, Texas, and by Zhao et al. (2018) for different corn varieties grown in the Texas Panhandle. Soil water sensing data were averaged and recorded every $15 \mathrm{~min}$. The hybrid irrigation scheduling method is referred hereafter as hybrid-NP or as hybrid-TDR if soil water sensing feedback data were obtained from NP measurements or TDR sensors, respectively.

\section{IRRIGATION MANAGEMENT USING ARSPIVOT}

During both growing seasons, scans of the field using the lateral-mounted IRTs were performed approximately every third day. ARSPivot generated prescription maps on days following a scan by comparing the iCWSI values obtained from the scan and the average SWDr obtained from NP measurements (2016 season) and from TDRs (2017 season) against pre-established iCWSI and SWDr thresholds used in the first (table 1) and second (table 2) case studies, respectively. A two-point calibration is performed to evaluate the measurement of each TDR probe in Pullman soil wetted to field capacity and dried to its permanent wilting point. Andrade et al. (2020) describe the formulas implemented in ARSPivot to determine if an MZ (experimental plot) will be irrigated and, if so, in what amount, based on the iCWSI values obtained inside the MZ. According to those formulas, a plot irrigated using the iCWSI irrigation scheduling method at the $80 \%$ level (C80) during the 2016 season would receive: (1) no irrigation when $\mathrm{iCWSI}_{x} \leq 100$ for the majority of $\mathrm{iCWSI}_{x}$ values obtained inside the plot, (2) a minimum depth of $12.7 \mathrm{~mm}$ when $100<\mathrm{iCWSI}_{x} \leq 150$ for the majority of $\mathrm{iCWSI}_{x}$ values inside the plot, (3) a medium depth of $19.1 \mathrm{~mm}$ when $150<\mathrm{iCWSI}_{x}$ $\leq 250$ for the majority of $\mathrm{iCWSI}_{x}$ values inside the plot, or (4) a maximum depth of $25.4 \mathrm{~mm}$ when $\mathrm{iCWSI}_{x}>250$ for the majority of $\mathrm{iCWSI}_{x}$ values inside the plot (table 1). A plot irrigated using the hybrid-NP irrigation scheduling method (H80) during the 2016 season would receive: (1) no irrigation when the average soil water depletion in the root zone inside the plot SWDr $<0.2$, (2) a maximum depth of $25.4 \mathrm{~mm}$ when $\mathrm{SWD} r>0.5$, or (3) an irrigation depth assigned by the iCWSI irrigation scheduling method when $0.2 \leq \mathrm{SWD} r \leq 0.5$ (table 1). The formulas described by Andrade et al. (2020) can be applied to MZs of any size or shape and thus were applied to manage the irrigation scheduling of plots in the NNW and SSE sides during both growing seasons.

Irrigations were triggered by the server program of ARSPivot and controlled using its client program, which automatically submitted commands to the control panel to enable the application of irrigation depths specified in the sitespecific prescription maps. To irrigate the NNW side of the field using VRI zone control, the client sent commands to set the center pivot speed constant and to turn the VRI zone control on immediately after the center pivot lateral pipeline entered the perimeter of the NNW side. To irrigate the SSE side of the field using VRI speed control, the client sent commands to turn the VRI zone control off and to change the center pivot speed immediately after the center pivot lateral pipeline entered the perimeter of any of the eight plots in the SSE side. The specified center pivot speed matched the irrigation depth prescribed to the treatment plot where the center pivot was located. The client also sent commands to turn the water off and increase the center pivot speed immediately after the center pivot lateral entered the perimeter of an MZ designated as a road or an angular sector with no irrigation (fig. 1).

\section{Geospatial data Presentation}

Color scale maps of the iCWSI, ET , grain yield, and field elevation were generated in ARSPivot by importing $X Y Z$ points and storing them in a CSV file. The $X$ and $Y$ values represent the geographic coordinates (longitude and latitude) 
of approximate locations for the $Z$ values $=\left\{\mathrm{iCWSI}, \mathrm{ET}_{\mathrm{c}}\right.$, grain yield $\}$. ARSPivot software uses a built-in kriging interpolation method with an exponential semi-variogram model to build contour maps. Filled contour maps of elevations were generated in ARSPivot using elevation data obtained from Google Maps API through an external script written in the $\mathrm{R}$ programming language and the Googleway package for the same language (Cooley, 2017). A contour maps is displayed as a bottom layer in the main panel of the ARSPivot software GUI so that users can analyze the relationship of irrigation management to the spatial distribution of $Z$ values (or vice versa). Graphic combining of filled contour map, color scale maps, and the perimeters of MZs can be useful during postharvest analysis so that users can identify patterns in their fields that may be causing appreciable differences in yields, or before the start of a new growing season to delineate (or adjust) MZs based on elevations, soils, and crop performance.

\section{Statistical Analysis of DAta}

Grain samples were collected by hand near the center of each plot in the NNW side of the field. For plots in the SSE side of the field, three grain samples were collected approximately along the axis of symmetry of each plot, equidistant from each other (near the center of sprinkler zones 8, 9, and 10) (fig. 3). Seasonal water use was calculated as the sum of precipitation, irrigation water applied, and the change in soil water storage to a depth of $2.3 \mathrm{~m}$ during the growing season. Runoff was assumed to be negligible due to the use of furrow diking. The CWP was calculated as the ratio of dry grain yield to seasonal water use. Results were analyzed through analysis of variance (ANOVA) and Tukey's honest significant difference (HSD) procedures using $\mathrm{R}$ statistical software (R Core Team, 2020) and the Agricolae package of statistical procedures for R software (Mendiburu, 2020).

\section{RESULTS}

\section{Climate}

Annual and within-season precipitation (June through October) was less than average for Bushland in 2016 and greater than average in 2017 (table 3). In 2016, a uniform post-plant irrigation of $13 \mathrm{~mm}$ was applied on DOY 140 (May 19, 2016) and was followed by 15 days of cloud cover and precipitation totaling approximately $25 \mathrm{~mm}$. On DOY
161 (June 9), DOY 171 (June 19), and DOY 177 (June 25), irrigations at $80 \%$ replenishment of soil water depletion to FC were applied to the M80 and C80 treatment plots, irrigations at $50 \%$ replenishment of soil water depletion to $\mathrm{FC}$ were applied to the M50 and C50 treatment plots, and irrigations at $30 \%$ replenishment of soil water depletion to FC were applied to the M30 and U30 treatment plots. Soil water depletion was based on weekly NP readings from the M80 plots. This was to help ensure water treatment effects. A hailstorm occurred on DOY 165 (June 13).

In 2017, due to lack of precipitation in late May, two postplant irrigations of $19 \mathrm{~mm}$ and $25 \mathrm{~mm}$ were applied on DOY 160 (June 9) and DOY 165 (June 14) to ensure a uniform plant stand. Variable watering rates using the ISSCADA system were started in late June. A hailstorm far more damaging than the one in 2016 occurred on DOY 183 (July 2, 2017). More than $90 \%$ of leaves and corn stalks in the entire field were shredded, slowing crop maturity by approximately two weeks. Seasonal (May to Oct.) mean monthly reference evapotranspiration $\left(\mathrm{ET}_{\mathrm{o}}\right.$ ) was greatest in 2016 as compared with 2017, and drought conditions prevailed in May through early August of 2016.

\section{First CASE STUdy: SumMer 2016}

For the 2016 season, no significant differences were found in mean dry grain yield, seasonal water use, and crop water productivity (CWP) between the C80 and U80 treatment plots in the NNW side of the field (VRI zone control) (table 4). However, yield and $\mathrm{ET}_{\mathrm{c}}$ were significantly greater for the C50 plots as compared with the U50 plots (table 4). Mean dry grain yield and CWP for the C80 and C50 treatment plots were not significantly different, although the

Table 4. Mean dry grain yield $\left(\mathrm{Mg} \mathrm{ha}^{-1}\right)$, seasonal water use $\left(\mathrm{ET}_{\mathrm{c}}\right)(\mathrm{mm})$, and crop water productivity (CWP, $\mathrm{kg} \mathrm{m}^{-3}$ ) of plots located in the NNW side of the field and irrigated using VRI zone control during the 2016 season. Seasonal water use includes total precipitation of $222 \mathrm{~mm}$ measured during the season. ${ }^{[\mathrm{a}]}$

\begin{tabular}{cccc}
\hline $\begin{array}{c}\text { Irrigation Method } \\
\text { and Level }\end{array}$ & $\begin{array}{c}\text { Yield } \\
\left(\mathrm{Mg} \mathrm{ha}^{-1}\right)\end{array}$ & $\begin{array}{c}\text { Seasonal } \\
\text { Water Use } \\
(\mathrm{mm})\end{array}$ & $\begin{array}{c}\mathrm{CWP} \\
\left(\mathrm{kg} \mathrm{m}^{-3}\right)\end{array}$ \\
\hline U80 & $16.8 \mathrm{a}$ & $670 \mathrm{ab}$ & $2.51 \mathrm{ab}$ \\
C80 & $17.2 \mathrm{a}$ & $694 \mathrm{a}$ & $2.48 \mathrm{ab}$ \\
U50 & $11.7 \mathrm{~b}$ & $548 \mathrm{c}$ & $2.14 \mathrm{~b}$ \\
C50 & $16.4 \mathrm{a}$ & $651 \mathrm{~b}$ & $2.52 \mathrm{a}$ \\
\hline [a] Values with the same letter in each column are not significantly differ-
\end{tabular}
ent at the 0.05 probability level based on Tukey's HSD test.

Table 3. Mean meteorological data reported monthly for growing seasons 2016 and 2017 at Bushland, Texas. Short crop reference ET (ET $)_{0}$ was calculated according to ASCE (2005).

\begin{tabular}{|c|c|c|c|c|c|c|c|c|c|}
\hline & & \multirow{2}{*}{$\begin{array}{l}\text { Cumulative } \\
\text { Precipitation } \\
(\mathrm{mm})\end{array}$} & \multicolumn{2}{|c|}{$\begin{array}{c}\text { Air Temperature } \\
\left({ }^{\circ} \mathrm{C}\right) \\
\end{array}$} & \multicolumn{2}{|c|}{$\begin{array}{c}\text { Relative Humidity } \\
\text { (RH, \%) }\end{array}$} & \multirow{2}{*}{$\begin{array}{c}\text { Solar } \\
\text { Irradiance } \\
\left(\mathrm{MJ} \mathrm{m}^{-2} \mathrm{~d}^{-1}\right)\end{array}$} & \multirow{2}{*}{$\begin{array}{l}\text { Wind } \\
\text { Speed } \\
\left(\mathrm{m} \mathrm{s}^{-1}\right)\end{array}$} & \multirow{2}{*}{$\begin{array}{c}\mathrm{ET}_{\mathrm{o}} \\
\left(\mathrm{mm} \mathrm{d}^{-1}\right)\end{array}$} \\
\hline \multicolumn{2}{|c|}{ Yeah and Month } & & Maximum & Minimum & Maximum & Minimum & & & \\
\hline \multirow[t]{6}{*}{2016} & May & 31.5 & 25.3 & 9.3 & 88.8 & 30.8 & 24.3 & 4.7 & 5.9 \\
\hline & June & 35 & 33.0 & 17.2 & 90.2 & 27.1 & 26.2 & 3.9 & 7.0 \\
\hline & July & 23 & 36.0 & 19.2 & 83.0 & 22.7 & 25.8 & 3.7 & 7.5 \\
\hline & Aug. & 178 & 31.0 & 17.0 & 97.4 & 36.3 & 20.7 & 3.0 & 4.7 \\
\hline & Sept. & 21 & 28.9 & 14.4 & 96.4 & 39.0 & 19.5 & 3.3 & 4.1 \\
\hline & Oct. & 0 & 27.2 & 8.9 & 81.9 & 22.9 & 15.9 & 4.7 & 5.6 \\
\hline \multirow[t]{6}{*}{2017} & May & 15.6 & 27.4 & 8.0 & 87.8 & 21.5 & 25.3 & 4.3 & 5.5 \\
\hline & June & 44.2 & 33.7 & 15.1 & 96.0 & 39.6 & 24.6 & 4.1 & 6.4 \\
\hline & July & 107.6 & 35.1 & 18.0 & 91.4 & 33.0 & 23.4 & 3.4 & 5.7 \\
\hline & Aug. & 189.4 & 29.8 & 16.3 & 98.5 & 49.9 & 20.6 & 3.0 & 3.8 \\
\hline & Sept. & 40.4 & 27.9 & 12.7 & 90.7 & 41.3 & 17.1 & 3.5 & 3.4 \\
\hline & Oct. & 84.0 & 23.0 & 6.4 & 94.9 & 42.2 & 15.0 & 4.4 & 3.4 \\
\hline
\end{tabular}


mean seasonal water use for the $\mathrm{C} 50$ plots was significantly less in comparison with the $\mathrm{C} 80$ plots.

The reason for the significantly greater mean $\mathrm{ET}_{\mathrm{c}}$ in the C50 plots as compared with the U50 plots in the NNW side of the field (VRI zone control) was due to the greater mean cumulative irrigation amount applied to the C50 treatment plots ( $348 \mathrm{~mm}$ ) as compared with the cumulative amount applied to the U50 treatment plots $(268 \mathrm{~mm})$. The C50 plots received a maximum irrigation depth for 12 of the 18 irrigation events occurring during the season due to high iCWSI values. Plants in the C50 treatment plots may not have been able to fully recover from the deficit irrigation in the month of June (four signaled at the minimum depth) when experiencing high evaporative demand in July as the crop entered the reproductive stage. Maximum irrigation depths were triggered when the plants in the C50 treatment plots entered the tasseling stage. The plants recovered slightly after two to three irrigations, as indicated by the triggering of a medium irrigation depth, followed by two irrigations triggered at the maximum level. This pattern repeated during the blistering and grain fill stages. Carroll et al. (2017) report elevated canopy temperatures for corn plants during the late vegetative and reproductive stage for corn receiving deficit irrigation ( $50 \%$ less than $100 \%$ ET) during the five-leaf to the ten-leaf growth stage. Data from the C30 and U30 plots were omitted from the analysis of results due to an error in the implementation of the iCWSI irrigation scheduling method in an earlier version of the server program, which caused the C30 plots to be irrigated at the $80 \%$ level. Although this error had been corrected, it was detected late in the season.

Table 5 presents the mean dry grain yield, $\mathrm{ET}_{\mathrm{c}}$, and CWP of plots irrigated at the $80 \%$ level on both sides of the field during the 2016 season. No significant differences were found between any of these indicators, regardless of the irrigation scheduling method or type of VRI method (zone control or speed control), which suggests that the ISSCADA system can be effectively used for irrigation management of center pivot systems using VRI zone control or VRI speed control. It is also reasonable given that the soil in this field is quite uniform despite the classification into Pullman A and Pullman B due

Table 5. Mean dry grain yield $\left(\mathrm{Mg} \mathrm{ha}^{-1}\right)$, seasonal water use (ET $\left.\mathrm{c}, \mathbf{m m}\right)$, and crop water productivity (CWP, $\mathrm{kg} \mathrm{m}^{-3}$ ) of plots assigned the $80 \%$ irrigation level during the 2016 season, grouped by (a) irrigation method and location in the field and (b) VRI application method. Seasonal water use includes total precipitation of $222 \mathrm{~mm}$ measured during the season. ${ }^{[a]}$

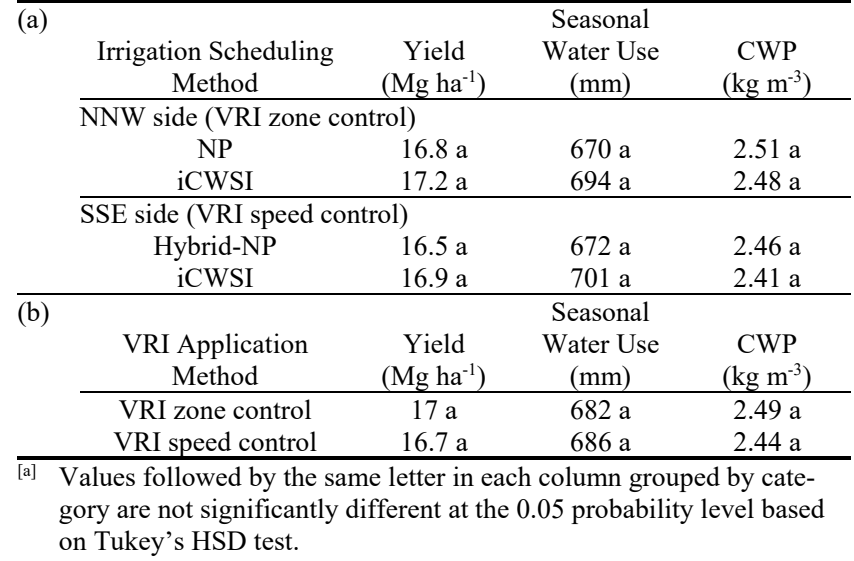

to minor slope differences. These results also indicate that the 12 IRTs mounted on the center pivot provided enough resolution to account for soil water variability within the plots irrigated with the iCWSI irrigation scheduling method using VRI speed control. Nevertheless, further research is recommended to identify an optimal spacing between IRTs that minimizes their cost without affecting the performance of irrigation scheduling methods making use of them.

The mean dry grain yield, $\mathrm{ET}_{\mathrm{c}}$, and $\mathrm{CWP}$ of plots irrigated with the NP (NNW side of the field, VRI zone control) and hybrid-NP irrigation scheduling methods (SSE side of the field, VRI speed control) were similar, which indicates that irrigation depths assigned by the latter method were mainly determined by the first step of the hybrid-NP irrigation scheduling method. In other words, the SWD $r$ estimated for plots irrigated with this method determined their irrigation depths more frequently (on average, for 11 of 18 irrigation events) than did the iCWSI values calculated for these plots. Different results would likely follow if the SWD $r$ thresholds were changed to reduce their influence and increase the range under which iCWSI values were used to assign irrigation depths. However, the identification of optimal SWDr thresholds was beyond the scope of this study, and further research in this direction is recommended.

Results obtained from plots in the SSE side of the field (VRI speed control) showed no significant difference in mean grain yields and CWP for plots using the hybrid-NP and iCWSI irrigation scheduling methods (table 5). The hybrid-NP irrigation method reduced $\mathrm{ET}_{\mathrm{c}}$ in comparison to the iCWSI irrigation scheduling method, but the reduction was not statistically significant (table 5).

\section{Geospatial Presentation of Field Data}

Figure 2 shows color scale maps of the iCWSI values calculated by ARSPivot for each cell in the 44 experimental plots (fig. 1a) using data collected during dry scans performed during daylight hours on DOY 180 (June 28, 2016) (fig. 2a) and DOY 184 (July 2, 2016) (fig. 2c). Cells are the smallest zones within which irrigation depths can be controlled with reasonable accuracy with a VRI center pivot. Additional details of cells and how they are grouped to form MZs can be found in Andrade et al. (2020). Prescription maps generated (and applied) on days following both scans are presented in figures $2 b$ and $2 d$, respectively. The maps indicate spatial and temporal differences in the iCWSI and the resulting decision support in the form of dynamic prescription maps. If the majority of iCWSI values inside a C80 plot were larger than 250 (table 1), then the plot was assigned the maximum irrigation depth $(25.4 \mathrm{~mm})$. In this scenario, the majority of cells in a plot with the $80 \%$ irrigation level would fall in the fourth category of the color scale (bright red). Similarly, if the majority of iCWSI values fell in the third (orange) or second (yellow) categories, then the plot was assigned a medium $(19.1 \mathrm{~mm})$ or minimum $(12.7 \mathrm{~mm})$ irrigation depth, respectively. No irrigation was assigned otherwise.

The color scale for the iCWSI values in figure 2 consists of four categories whose limits correspond to the iCWSI thresholds used for plots assigned the $80 \%$ irrigation treatment level in the first study (table 1). This color scale allows 


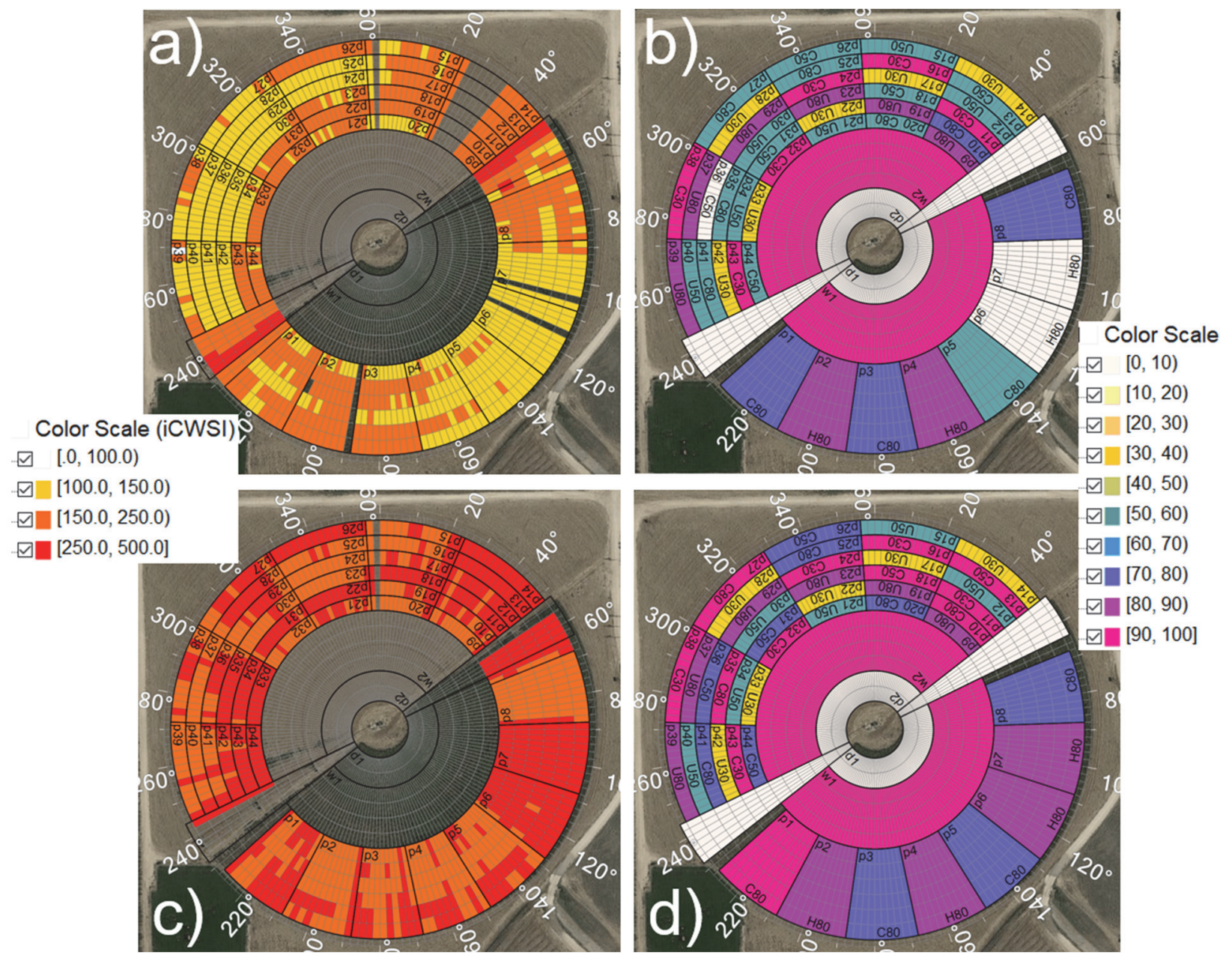

Figure 2. Color scale maps of integrated crop water stress index (iCWSI) plotted for cells located inside experimental plots using data collected by dry scans performed on (a) June 28 and (c) July 2, 2016. The color scale on the left represents iCWSI values. The scale progresses from white (least stress) to orange (medium stress) to red (greatest stress). Prescription maps next to the color scale maps were generated by the server program (and applied by the center pivot under control of the client program) on (b) June 29 and (d) July 3, 2016, using data collected during the scan preceding each irrigation. The color scale on the right represents irrigation depths, which are shown as percentages of a maximum depth of $25.4 \mathrm{~mm}$ (table 1). Capital letters inside the plots indicate the irrigation scheduling method used for the plot: $\mathrm{C}=\mathrm{iCWSI}, \mathrm{U}=\mathrm{NP}$, and $\mathrm{H}=\mathrm{hybrid}-$ NP. Numbers following the capital letters indicate the irrigation level assigned to the plot $(80 \%, 50 \%$, or $30 \%)$.

users to identify, at a glance, which plots experienced enough plant stress to receive irrigation and the amount of their prescriptions. For example, the color scale maps in figure $2 \mathrm{a}$ help to explain why $\mathrm{C} 80$ plot $\mathrm{p} 1$ received an irrigation depth of $19.1 \mathrm{~mm}$ on DOY 181; most of its cells were colored orange, indicating $150<\mathrm{iCWSI} \leq 250$ (table 1$)$. The same plot received an irrigation depth of $25.4 \mathrm{~mm}$ during the following irrigation on DOY 185; accordingly, most of its cells were colored bright red (iCWSI $>250$ ) in figure 2c.

Similar color scale maps of canopy temperature values can be generated for any date during the growing season when a dry scan or an irrigation event took place. These maps can be created any time starting one day after the sensing data were collected. Color scale maps can help users better understand the site-specific irrigation scheduling algorithms implemented in the ARSPivot software and remove the perception of decision-making as a black box. Color scale maps can also help users to keep track of changes in canopy temperatures or iCWSI values, which can be useful for the identification of potential sources of plant stress.
Additional types of maps can be generated with ARSPivot to assist the inspection of multiple numerical properties of cells or MZs. Figure 3 shows a color scale map of dry grain yield and seasonal water use for all plots in the field irrigated at the $80 \%$ level. This map helps to identify if the crop performance of such plots had any spatial distribution pattern. Yields are represented by small circles whose interiors are colored using a graphic scale that progresses from white (least yield) to orange (medium yield) to red (largest yield) (fig. 3). The color scale map (fig. 3) is displayed on top of a background satellite image of the threespan center pivot field and below a soil map to demonstrate how ARSPivot allows users to overlay multiple layers of information to facilitate spatial analysis of information relevant to the irrigation management of an ISSCADA center pivot system. ARSPivot automatically obtains satellite images and soil maps (for center pivot fields in the U.S.) using Google Maps API (Google, 2019) and the USDA-NRCS web soil survey API (NRCS, 2019), respectively.

Although no dominant pattern seemed to be involved in the spatial distribution of either yield or seasonal water use, 


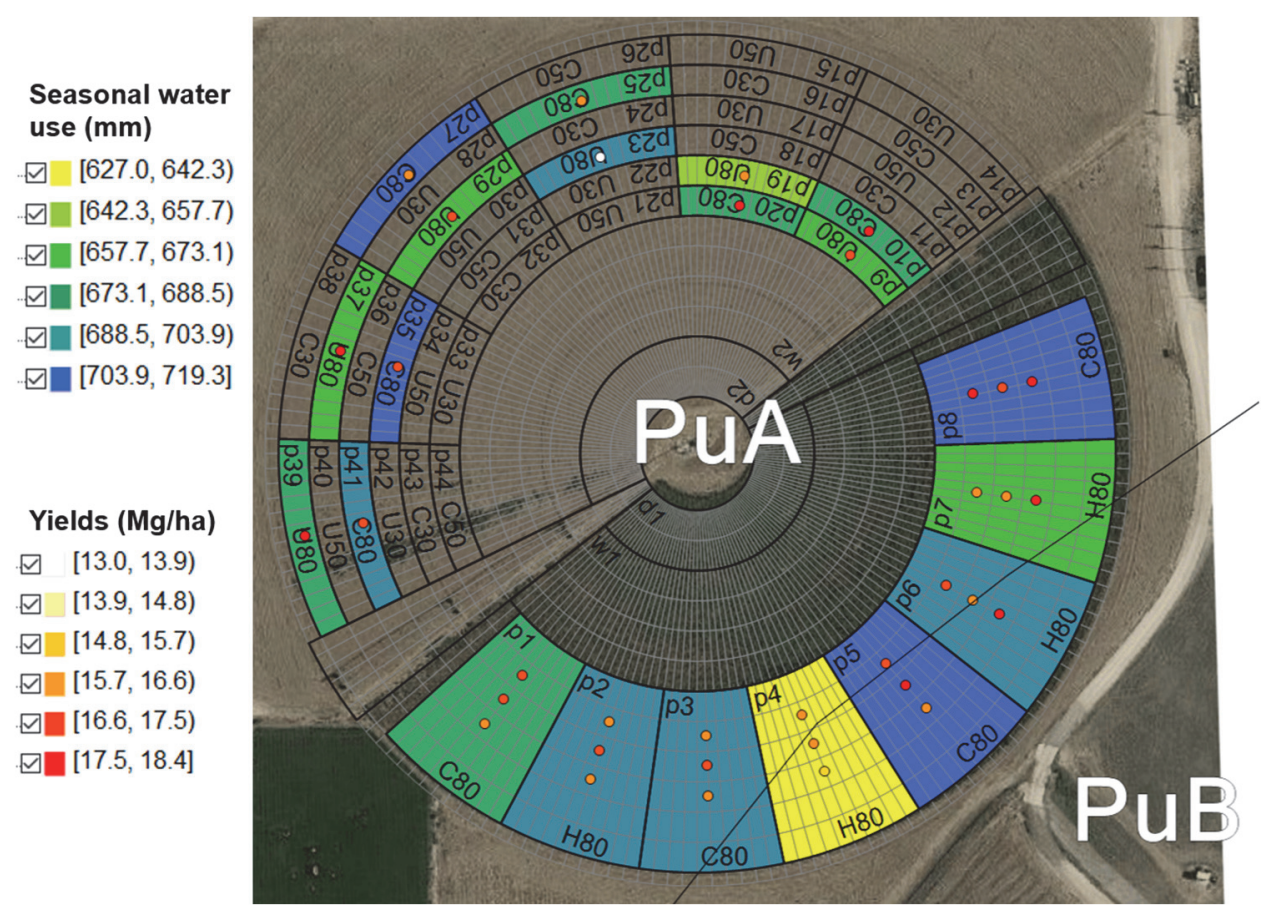

Figure 3. Color scale map of seasonal water use $(\mathrm{mm})$ and dry grain yield $\left(\mathrm{Mg} \mathrm{ha}^{-1}\right)$ of plots assigned the $80 \%$ irrigation level during the 2016 season. Circles inside the plots represent approximate locations where yields were sampled by hand. Seasonal water use is displayed using a color scale that progresses from yellow (least amount) to green (medium amount) to blue (largest amount). Yields are displayed using a color scale that progresses from white (least yield) to orange (medium yield) to red (largest yield). The color scale map is drawn on top of a background satellite image downloaded using Google Maps API (Google, 2019) and below a soil map downloaded using the USDA-NRCS web soil survey API (NRCS, 2019). The soil is a Pullman clay loam with $0 \%$ to $1 \%$ slopes $(\mathrm{PuA})$ and $1 \%$ to $3 \%$ slopes $(\mathrm{PuB})$.

the following trends can be observed in figure 3: among plots in the NNW side of the field, smaller seasonal water use amounts were required by four neighboring plots ( $\mathrm{p} 9, \mathrm{p} 10$, $\mathrm{p} 19$, and p20) located closer to the center pivot point than other plots. Similarly, among plots in the SSE side of the field, larger seasonal water use amounts and dry grain yields seemed to occur in four neighboring plots ( $\mathrm{p} 5$ to $\mathrm{p} 8$ ) in comparison with the other four plots (p1 to $\mathrm{p} 4$ ) in the SSE side (fig. 3).

Filled contour maps of elevation (fig. 4a) and yields (fig. 4b) obtained from plots irrigated at the $80 \%$ level show that a relationship seems to exist between larger yields and lower elevations in the east side of the field. However, in the west side of the field, such a relationship appears inconsistent. To determine if the positions of plots with respect to the center pivot point and the elevations at their centers have an effect on crop performance, each factor was analyzed by grouping plots into three categories and then comparing the mean dry grain yield, $\mathrm{ET}_{\mathrm{c}}$, and CWP of the plots in each category (table 6). The distance of plots from the center pivot point had no statistically significant impact on mean yield, $\mathrm{ET}_{\mathfrak{c}}$, or CWP. Elevation at the center of plots had no significant impact on $\mathrm{ET}_{\mathrm{c}}, \mathrm{CWP}$, or yield, although slightly larger yields were found at lower elevations. It should be noted that a more exhaustive analysis that includes results obtained from plots irrigated at the $50 \%$ and $30 \%$ irrigation levels or an analysis that uses a different type of statistical method may lead to different results. The purpose of the analysis presented here is to exemplify how field contour maps generated with ARSPivot can help users identify potential sources of variability regarding crop performance.

\section{SeCONd CASE STUdy: SuMmer 2017}

Mean dry grain yields obtained from plots in both the NNW and SSE sides of the field (tables 7 and 8) were considerably less than average yields obtained from their counterparts during the previous season (tables 4 and 5), probably due to hail damage. For plots in the NNW side of the field (using VRI zone control), no significant differences were found in terms of mean dry grain yield and CWP between the U80 and C 80 treatment plots, although the U80 plots had a smaller and significantly different $\mathrm{ET}_{\mathrm{c}}$ (table 7). Analogous results were observed when comparing grain yields and CWP obtained from U50 plots to those from C50 plots, as well as when comparing results obtained from U30 plots to those from C30 plots (table 7). No significant differences were found between the mean dry grain yields and CWP of plots irrigated at the $80 \%$ and $50 \%$ irrigation levels nor between the same indicators for C50 and C30 treatment plots (table 7). These results indicate that using the same iCWSI thresholds but different irrigation depths for each of the irrigation levels for all $\mathrm{C}$ plots resulted in similar grain yield and CWP values with respect to the NP irrigation scheduling method. The use of the same iCWSI thresholds but different irrigation depths has been applied in subsequent studies using the iCWSI method for site-specific irrigation scheduling of corn (Stone et al., 2020), soybean (Sui et al., 2020), and potatoes (O'Shaughnessy et al., 2020).

Table 8 presents the overall mean dry grain yield, $\mathrm{ET}_{\mathrm{c}}$, and CWP of plots irrigated at the $80 \%$ level by irrigation scheduling method and by VRI method (zone vs. speed control) from both sides of the field during the 2017 season. No significant differences were found between the mean dry 

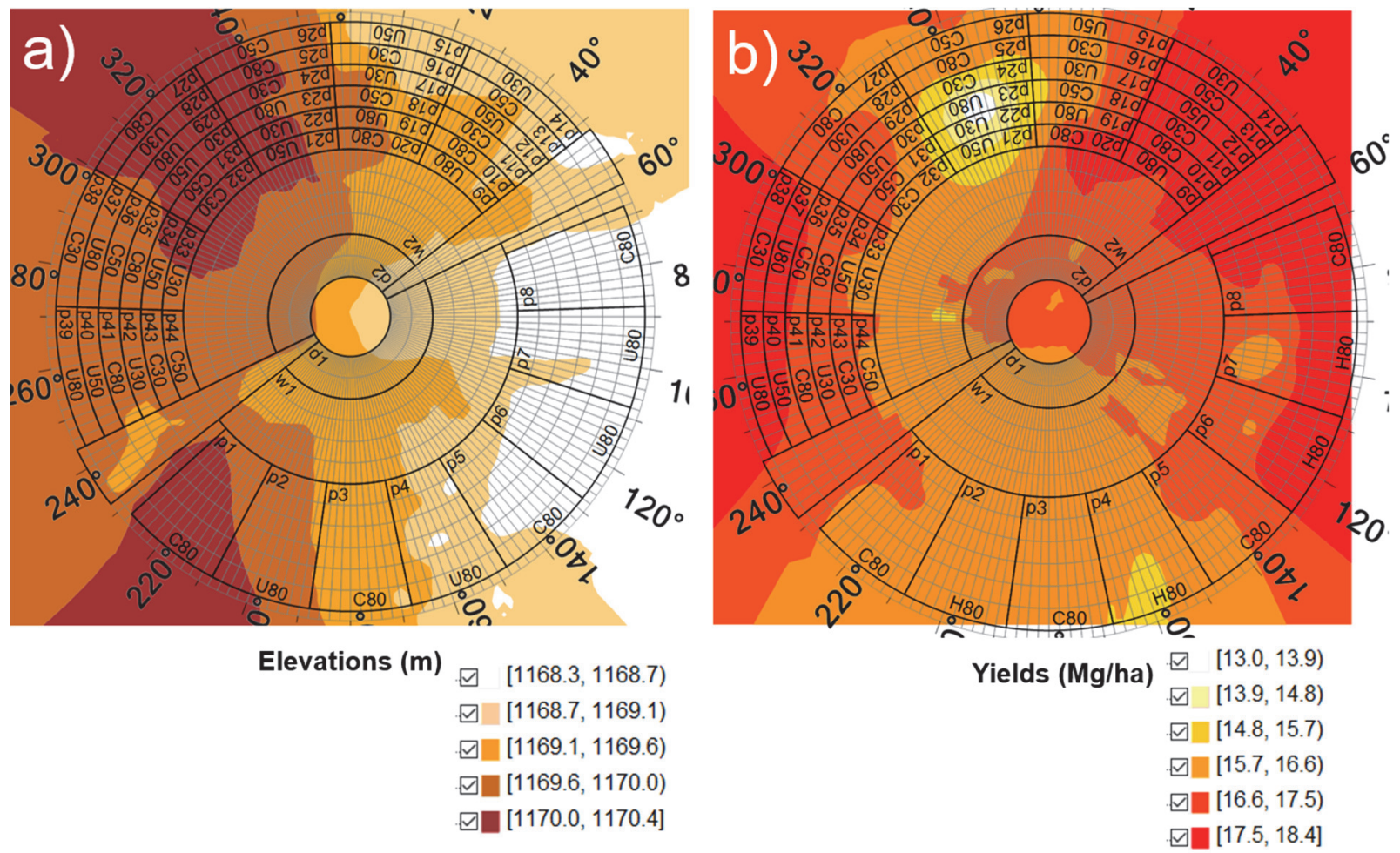

Figure 4. Filled contour maps of (a) elevation (m) and (b) dry grain yields $\left(\mathrm{Mg} \mathrm{ha}^{-1}\right)$ obtained from plots irrigated at the $80 \%$ level. ARSPivot generated the maps with a built-in kriging interpolation method using an exponential semi-variogram model. Elevations are displayed using a color scale that progresses from white (lowest elevation) to orange (medium elevation) to brown (highest elevation). Yields are displayed using a color scale that progresses from white (least yield) to orange (medium yield) to red (largest yield).

Table 6. Mean dry grain yield $\left(\mathrm{Mg} \mathrm{ha}^{-1}\right)$, seasonal water use $\left(\mathrm{ET}_{\mathrm{c}}, \mathrm{mm}\right)$, and CWP $\left(\mathrm{kg} \mathrm{m}^{-3}\right)$ of plots in the field assigned the $80 \%$ irrigation level during the 2016 season, grouped by (a) distance from location of yield sample to center pivot point, and (b) elevation at location of yield

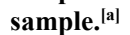

\begin{tabular}{|c|c|c|c|c|}
\hline \multirow[t]{5}{*}{ (a) } & & \multicolumn{3}{|c|}{ Seasonal } \\
\hline & $\begin{array}{l}\text { Distance } \\
\text { (m) }\end{array}$ & $\begin{array}{c}\text { Yield } \\
\left(\mathrm{Mg} \mathrm{ha}^{-1}\right)\end{array}$ & $\begin{array}{c}\text { Water Use } \\
(\mathrm{mm})\end{array}$ & $\begin{array}{c}\text { CWP } \\
\left(\mathrm{kg} \mathrm{m}^{-3}\right)\end{array}$ \\
\hline & Less than 90 & $16.9 \mathrm{a}$ & $679 \mathrm{a}$ & $2.5 \mathrm{a}$ \\
\hline & 90 to 100 & $16.4 \mathrm{a}$ & $689 \mathrm{a}$ & $2.38 \mathrm{a}$ \\
\hline & Greater than 100 & $17 \mathrm{a}$ & $687 \mathrm{a}$ & $2.48 \mathrm{a}$ \\
\hline \multirow[t]{5}{*}{ (b) } & & & Seasonal & \\
\hline & $\begin{array}{c}\text { Elevation } \\
(\mathrm{m})\end{array}$ & $\begin{array}{c}\text { Yield } \\
\left(\mathrm{Mg} \mathrm{ha}^{-1}\right)\end{array}$ & $\begin{array}{c}\text { Water Use } \\
(\mathrm{mm})\end{array}$ & $\begin{array}{c}\text { CWP } \\
\left(\mathrm{kg} \mathrm{m}^{-3}\right)\end{array}$ \\
\hline & Lower than $1,168.7$ & $17.1 \mathrm{a}$ & $687 \mathrm{a}$ & $2.49 \mathrm{a}$ \\
\hline & $1,1168.7$ to $1,169.8$ & $16.9 \mathrm{a}$ & $675 \mathrm{a}$ & $2.51 \mathrm{a}$ \\
\hline & Higher than $1,169.8$ & $16.5 \mathrm{a}$ & $693 \mathrm{a}$ & $2.38 \mathrm{a}$ \\
\hline
\end{tabular}

[a] Values followed by the same letter in each column grouped by category were not significantly different at the 0.05 probability level based on Tukey's HSD test.

Table 7. Mean dry grain yield $\left(\mathrm{Mg} \mathrm{ha}^{-1}\right)$, seasonal water use $\left(\mathrm{ET}_{\mathrm{c}}, \mathbf{m m}\right)$, and CWP $\left(\mathrm{kg} \mathrm{m}^{-3}\right)$ of plots located in the NNW side of the field and irrigated using VRI zone control during the 2017 season. Seasonal water use includes total precipitation of $452 \mathrm{~mm}$ measured during the season. ${ }^{[a]}$

\begin{tabular}{lccc}
\hline $\begin{array}{c}\text { Irrigation } \\
\text { Method } \\
\text { and Level }\end{array}$ & $\begin{array}{c}\text { Yield } \\
\left(\mathrm{Mg} \mathrm{ha}^{-1}\right)\end{array}$ & $\begin{array}{c}\text { Seasonal } \\
\text { Water Use } \\
(\mathrm{mm})\end{array}$ & $\begin{array}{c}\mathrm{CWP} \\
\left(\mathrm{kg} \mathrm{m}^{-3}\right)\end{array}$ \\
\hline U80 & $11.9 \mathrm{a}$ & $687 \mathrm{a}$ & $1.73 \mathrm{a}$ \\
$\mathrm{C} 80$ & $11.9 \mathrm{a}$ & $730 \mathrm{~b}$ & $1.63 \mathrm{a}$ \\
$\mathrm{U} 50$ & $11.4 \mathrm{ab}$ & $644 \mathrm{c}$ & $1.77 \mathrm{a}$ \\
$\mathrm{C} 50$ & $11.3 \mathrm{ab}$ & $663 \mathrm{~d}$ & $1.7 \mathrm{a}$ \\
$\mathrm{U} 30$ & $7.5 \mathrm{c}$ & $604 \mathrm{e}$ & $1.25 \mathrm{~b}$ \\
$\mathrm{C} 30$ & $9.5 \mathrm{bc}$ & $622 \mathrm{f}$ & $1.52 \mathrm{ab}$ \\
\hline a] & \multicolumn{4}{l}{} \\
Values followed by the same letter in each column were not signifi- \\
cantly different at the 0.05 probability level based on Tukey's HSD \\
test.
\end{tabular}

grain yields and CWP of such plots, regardless of their irrigation scheduling method or VRI method (table 8). However, the mean seasonal water use for plots irrigated with the NP irrigation scheduling method was smaller and significantly different from the mean seasonal water use for plots irrigated with the iCWSI and hybrid-TDR methods (table 8). The larger seasonal crop water use for the ISSCADA-iCWSI and hybrid-TDR treatment plots were mainly due to the maximum irrigation depths signaled after DOY 194 (July 13) through the end of the irrigation season on DOY 219 (August 7). These depths were greater than the amounts required by treatment plots using the NP irrigation scheduling method. The reduction in leaf area and the damage to plant stalks caused by the hailstorm likely resulted in the ISSCADA treatment plots signaling high iCWSI values, resulting in the application of the maximum irrigation depth. Results obtained from plots in the SSE side of the field indicated no significant difference between mean dry grain yield and CWP of plots irrigated with the hybrid-TDR and iCWSI irrigation scheduling methods (table 8).

To facilitate the use of the hybrid-TDR irrigation scheduling method, ARSPivot incorporates a graphic tool that generates time series charts of volumetric water contents measured by each set of TDRs within a soil water sensing station located in the field (fig. 5). Note that the volumetric water content measurements for the three TDR sensors on DOY 241 (August 29) are larger than field capacity for the two TDRs located nearest to the soil surface. This can be explained by the heavy rainfall $(121 \mathrm{~mm})$ received from DOY 221 (August 9) through DOY 237 (August 25) and the 
Table 8. Mean dry grain yield $\left(\mathrm{Mg} \mathrm{ha}^{-1}\right)$, seasonal water use $\left(\mathrm{ET}_{\mathfrak{c}}, \mathbf{m m}\right)$ and CWP $\left(\mathrm{kg} \mathrm{m}^{-3}\right)$ of plots assigned to the $80 \%$ irrigation level during the 2017 season, grouped by (a) irrigation method and location in the field, and (b) VRI application method. Seasonal water use includes total precipitation of $452 \mathrm{~mm}$ measured during the season. ${ }^{[a]}$

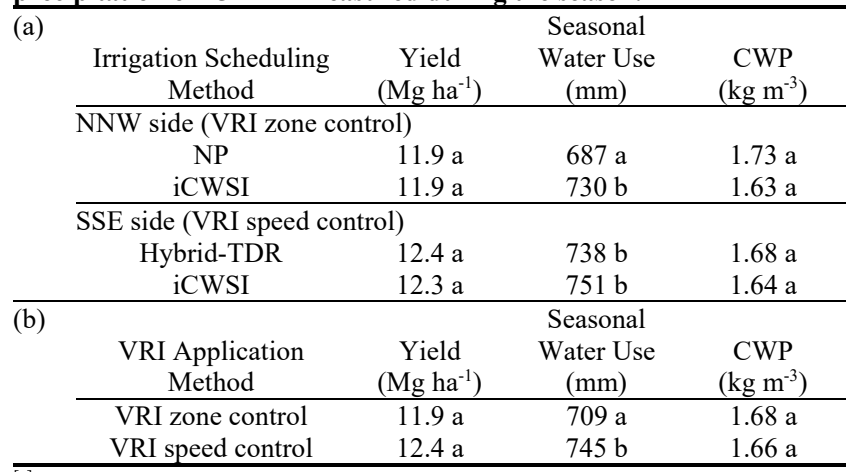

[a] Values followed by the same letter in each column grouped by category were not significantly different at the 0.05 probability level based on Tukey's HSD test.

slow water infiltration of the clay soils. Evett et al. (2019) discussed large TDR measurements for Acclima TDR soil water sensors in soil where clay impeded water flow. Users can select to display a time series of the last $24 \mathrm{~h}$, the last 3 days, the last 7 days, or the entire growing season for each TDR sensor in a sensing station. Users can also choose to include the field capacity and wilting point at one of the depths where a TDR probe has been positioned (fig. 5). This tool can help users monitor soil water content changes over time and, in combination with color scale maps of iCWSI values, can help them scrutinize the irrigation depths recommended by the hybrid-TDR method.

\section{Conclusions}

A software program, named ARSPivot, was used to operate a complex system comprised of a VRI center pivot system and a network of soil water, plant, and microclimate sensing systems supporting site-specific irrigation scheduling methods based on plant stress and soil water status. A post-harvest analysis of two experiments carried out in Bushland, Texas, during the summers of 2016 and 2017 demonstrated how ARSPivot could be used to assist the integrated irrigation management of VRI center pivot systems under a wide range of conditions.

ARSPivot facilitated the comprehensive irrigation management of both experiments, from the setting up of a computerized representation of the VRI center pivot system and plant and soil water sensing systems to the generation, application, and monitoring of site-specific prescription maps automatically generated by the software. ARSPivot's GUI incorporates geographic information system (GIS) tools that can help users make better informed decisions regarding irrigation management, as exemplified by the color scale and filled contour maps generated by ARSPivot using data collected during the 2016 season.

Results obtained during the 2016 season for plots irrigated at the $80 \%$ level on both sides of the field indicated no significant differences in mean dry grain yield, $\mathrm{ET}_{\mathrm{c}}$, and CWP of the experimental plots, regardless of the irrigation scheduling method or the VRI control method used for irrigation. No significant differences were found between mean dry grain yield, $\mathrm{ET}_{\mathrm{c}}$, and CWP of plots in the NNW side irrigated using VRI zone control and the iCWSI and NP irrigation scheduling methods at the $80 \%$ level. These indicators were larger and significantly different for plots irrigated

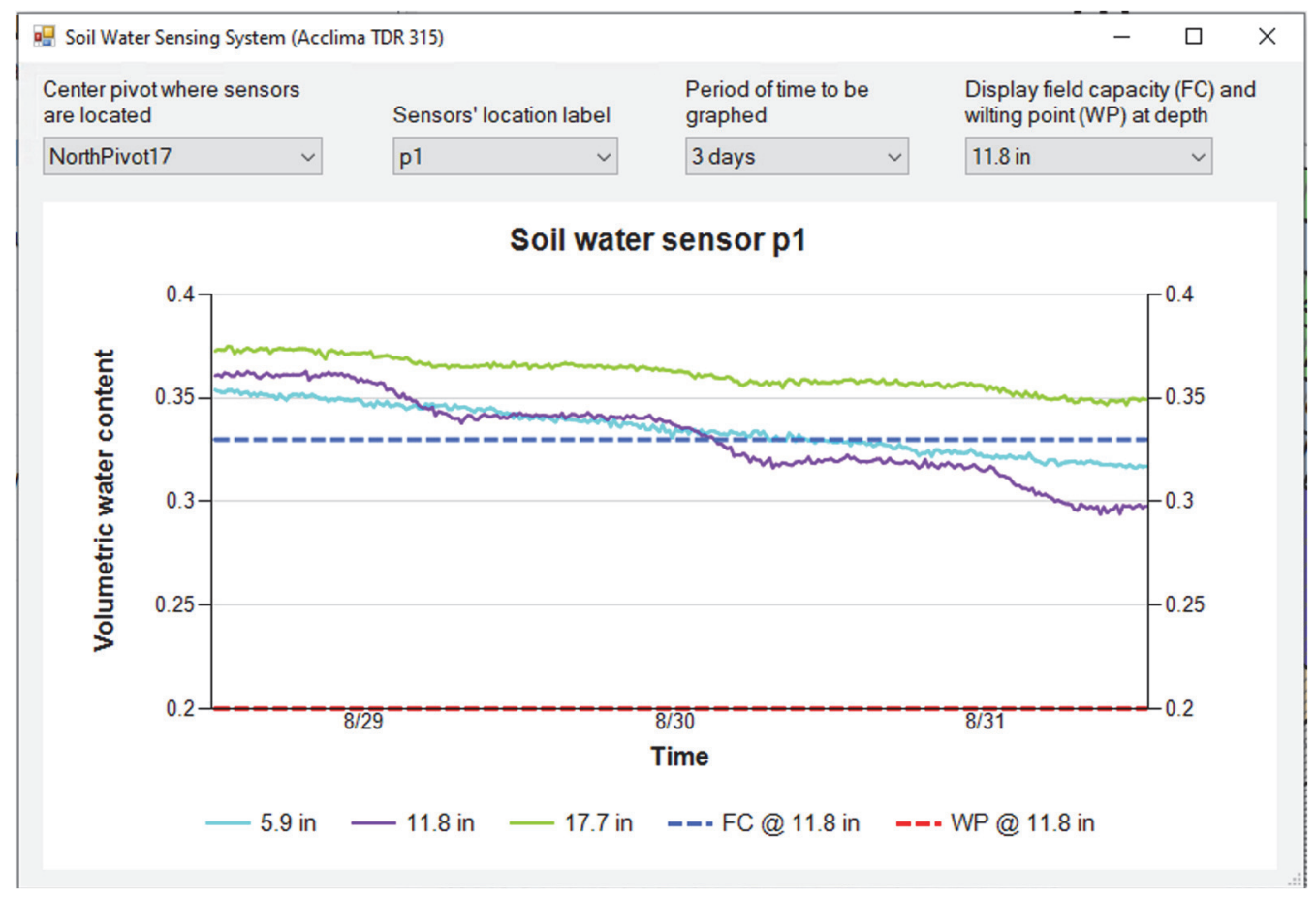

Figure 5. Time series of volumetric water content measured by three TDR sensors located inside plot p1 irrigated using the hybrid-TDR method during the 2017 growing season (fig. 1b). Sensors were installed at depths of $15 \mathrm{~cm}(5.9 \mathrm{in}$.), $30 \mathrm{~cm}(11.8 \mathrm{in}$.), and $45 \mathrm{~cm}(17.7 \mathrm{in}$.). The blue dashed line represents the field capacity (FC) of $0.33 \mathrm{~m}^{3} \mathrm{~m}^{-3}$, and the red dashed line represents the permanent wilting point (WP) of $0.19 \mathrm{~m}^{3} \mathrm{~m}^{-3}$. 
using the iCWSI irrigation scheduling method in comparison with plots using the NP irrigation scheduling method at the $50 \%$ level.

Results obtained during the 2017 season for plots irrigated at the $80 \%$ level on both sides of the field indicated no significant differences in mean dry grain yield and CWP, regardless of the irrigation scheduling method or the VRI method (zone or speed control) used for irrigation. No significant differences were found between mean dry grain yield and CWP of plots in the NNW side irrigated using the iCWSI and NP irrigation scheduling methods when compared at each irrigation level.

Overall, the success of the ISSCADA system was demonstrated by the lack of significant differences in yield and CWP between the ISSCADA system (with either iCWSI or iCWSI-hybrid-TDR algorithms) and irrigation scheduling based on NP. Irrigation scheduling based on weekly NP readings has heretofore been considered the best scientific irrigation scheduling method. Replicating its performance using an automated sensing and control system that does not require time-consuming and expensive travel and manual infield NP measurements represents an important advance in making science-based irrigation management available as a user-friendly system that does not require large amounts of labor, yet provides high yield and CWP.

\section{ACKNOWLEDGEMENTS}

This material is based upon work that is supported by the USDA National Institute of Food and Agriculture under Award No. 2016-67021-24420. The work reported in this article was also accomplished as part of a Cooperative Research and Development agreement between USDA-ARS and Valmont Industries, Inc., Valley, Nebraska (Agreement No. 58-3K95-0-1455-M).

\section{REFERENCES}

Al-Gaadi, K. A., \& Ayers, P. D. (1999). Integrating GIS and GPS into a spatially variable-rate herbicide application system. Appl. Eng. Agric., 15(4), 255-262. https://doi.org/10.13031/2013.5773

Allen, R. G., Pereira, L. S., Raes, D., \& Smith, M. (1998). Crop evapotranspiration: Guidelines for computing crop water requirements. FAO Irrigation and Drainage Paper No. 56. Rome, Italy: United Nations FAO.

Andrade, M. A., O’Shaughnessy, S. A., \& Evett, S. R. (2020). ARSPivot, a sensor-based decision support software for variable-rate irrigation center pivot systems: Part A. Development. Trans. ASABE, 63(5), https://doi.org/10.13031/trans.13907, in press.

ArcGIS. (2020). ArcGIS: The mapping and analytics platform. Redlands, CA: ESRI. Retrieved from https://www.esri.com/enus/arcgis/about-arcgis/overview.

ASCE. (2005). The ASCE standardized reference evapotranspiration equation. Technical committee on standardization of reference evapotranspiration. Reston, VA: ASCE. https://doi.org/10.1061/9780784408056

Backes, M., \& Plümer, L. (2003). On the adequacy of GISgenerated weed maps for precision farming. Proc. 9th Scandinavian Research Conf. on Geographical Information Sciences (pp. 261-268). Helsinki, Finland: Helsinki University of Technology.
Bakhsh, A., Colvin, T. S., Jaynes, D. B., Kanwar, R. S., \& Tim, U. S. (2000). Using soil attributes and GIS for interpretation of spatial variability in yield. Trans. ASAE, 43(4), 819-828. https://doi.org/10.13031/2013.2976

Barker, J. B., Heeren, D. M., Neale, C. M., \& Rudnick, D. R. (2018). Evaluation of variable-rate irrigation using a remotesensing-based model. Agric. Water Mgmt., 203, 63-74. https://doi.org/10.1016/j.agwat.2018.02.022

Blackmer, A. M., \& White, S. E. (1998). Using precision farming technologies to improve management of soil and fertiliser nitrogen. Australian J. Agric. Res., 49(3), 555-564. https://doi.org/10.1071/A97073

Carroll, D. A., Hansen, N. C., Hopkins, B. G., \& DeJonge, K. C. (2017). Leaf temperature of maize and crop water stress index with variable irrigation and nitrogen supply. Irrig. Sci., 35(6), 549-560. https://doi.org/10.1007/s00271-017-0558-4

Cooley, D. (2017). Googleway: Accesses Google Maps APIs to retrieve data and plot maps. R package ver. 2.2.0. Retrieved from https://CRAN.R-project.org/package=googleway

Evans, R., Han, S., Kroeger, M., \& Schneider, S. (1996). Precision center pivot irrigation for efficient use of water and nitrogen. Proc. Third Intl. Conf. Prec. Agric. (pp. 75-84). Madison, WI: ASA, CSSA, SSSA.

https://doi.org/10.2134/1996.precisionagproc3.c8

Evett, S. R. (2008). Chapter 3: Neutron moisture meters. In S. R. Evett, L. K. Heng, P. Moutonnet, \& M. L. Nguyen (Eds.), Field estimation of soil water content: A practical guide to methods, instrumentation, and sensor technology (pp. 39-54). IAEA-TCS30. Vienna, Austria: International Atomic Energy Agency. Retrieved from https://wwwpub.iaea.org/MTCD/Publications/PDF/TCS-30_web.pdf

Evett, S. R., Howell, T. A., Schneider, A. D., Upchurch, D. R., \& Wanjura, D. F. (1996). Canopy temperature based automatic irrigation control. In C. R. Camp (Ed.), Proc. Intl. Conf. Evapotranspiration and Irrigation Scheduling (pp. 207-213). St. Joseph, MI: ASAE.

Evett, S. R., O'Shaughnessy, S. A., \& Peters, R. T. (2014a). Irrigation scheduling and supervisory control and data acquisition system for moving and static irrigation systems. U.S. Patent No. 8,924,031 B1.

Evett, S. R., O'Shaughnessy, S. A., Andrade, M. A., Colaizzi, P. D., Schwartz, R. C., Schomberg, H. S., ... Sui, R. (2020). Theory and development of a VRI decision support system: The USDAARS ISSCADA approach. Trans. ASABE, 63(5), https://doi.org/10.13031/trans.13922, in press.

Evett, S. R., O’Shaughnessy, S. A., Colaizzi, P. D., \& Schwartz, R. C. (2014b). Soil water sensing: Implications of sensor capabilities for variable-rate irrigation management. Proc. Technical Session, Irrigation Show and Education Conf. Falls Church, VA: Irrigation Association. Retrieved from https://www.irrigation.org/IA/FileUploads/IA/Resources/Techni calPapers/2014/2014IrrigationShowTechnicalPapers.pdf

Evett, S. R., Schwartz, R. C., Tolk, J. A., \& Howell, T. A. (2009). Soil profile water content determination: Spatiotemporal variability of electromagnetic and neutron probe sensors in access tubes. Vadose Zone J., 8(4), 926-941. https://doi.org/10.2136/vzj2008.0146

Evett, S. R., Stone, K. C., Schwartz, R. C., O'Shaughnessy, S. A., Colaizzi, P. D., Anderson, S. K., \& Anderson, D. J. (2019). Resolving discrepancies between laboratory-determined field capacity values and field water content observations: Implications for irrigation management. Irrig. Sci., 37(6), 751759. https://doi.org/10.1007/s00271-019-00644-4

Gerhards, R., Sokefeld, M., Timmermann, C., Kuhbauch, W., \& Williams, M. M. (2002). Site-specific weed control in maize, 
sugar beet, winter wheat, and winter barley. Prec. Agric., 3(1), 25-35. https://doi.org/10.1023/A:1013370019448

Google. (2019). Google maps platform: Maps static API. Montain View, CA: Google. Retrieved from https://developers.google.com/maps/documentation/mapsstatic/intro

Jackson, R. D., Idso, S. B., Reginato, R. J., \& Pinter Jr., P. J. (1981). Canopy temperature as a crop water stress indicator. Water Resour. Res., 17(4), 1133-1138. https://doi.org/10.1029/WR017i004p01133

Mendiburu, F. (2020). Agricolae: Statistical procedures for agricultural research. R package ver.1.3-2. Retrieved from https://CRAN.R-project.org/package=agricolae

Meron, M., Tsipris, J., Orlov, V., Alchanatis, V., \& Cohen, Y. (2010). Crop water stress mapping for site-specific irrigation by thermal imagery and artificial reference surfaces. Prec. Agric., 11(2), 148-162. https://doi.org/10.1007/s11119-009-9153-x

Nahry, A. H. E., Ali, R. R., \& Baroudy, A. E. (2011). An approach for precision farming under pivot irrigation system using remote sensing and GIS techniques. Agric. Water Mgmt., 98(4), 517531. https://doi.org/10.1016/j.agwat.2010.09.012

Neményi, M., Mesterházi, P. Á., Pecze, Z., \& Stépán, Z. (2003). The role of GIS and GPS in precision farming. Comput. Electron. Agric., 40(1-3), 45-55. https://doi.org/10.1016/S01681699(03)00010-3

Nielsen, D. C., \& Gardner, B. R. (1987). Scheduling irrigations for corn with the crop water stress index (CVVSI). Appl. Agric. Res., 2(5), 295-300.

NRCS. (2019). Web soil survey. Washington, DC: USDA-NRCS. Retrieved from http://websoilsurvey.nrcs.usda.gov/

O'Shaughnessy, S. A., Andrade, M. A., \& Evett, S. R. (2017). Using an integrated crop water stress index for irrigation scheduling of two corn hybrids in a semi-arid region. Irrig. Sci., 35(5), 451-467. https://doi.org/10.1007/s00271-017-0552-x

O’Shaughnessy, S. A., Andrade, M. A., Colaizzi, P. D., Workneh, F., Rush, C. M., Evett, S. R., \& Kim, M. (2020). Irrigation management of potatoes using sensor feedback: Texas High Plains. Trans. ASABE, 63(5), https://doi.org/10.13031/trans.13925, in press.

O'Shaughnessy, S. A., Evett, S. R., \& Colaizzi, P. D. (2015). Dynamic prescription maps for site-specific variable-rate irrigation of cotton. Agric. Water Mgmt., 159, 123-138. https://doi.org/10.1016/j.agwat.2015.06.001

O’Shaughnessy, S. A., Evett, S. R., Colaizzi, P. D., \& Howell, T. A. (2012). A crop water stress index and time threshold for automatic irrigation scheduling of grain sorghum. Agric. Water Mgmt., 107, 122-132. https://doi.org/10.1016/j.agwat.2012.01.018

Peralta, N. R., Costa, J. L., Balzarini, M., Castro Franco, M., Córdoba, M., \& Bullock, D. (2015). Delineation of management zones to improve nitrogen management of wheat. Comput. Electron. Agric., 110, 103-113.

https://doi.org/10.1016/j.compag.2014.10.017

Peters, R. T., \& Evett, S. R. (2004). Modeling diurnal canopy temperature dynamics using one-time-of-day measurements and a reference temperature curve. Agron. J., 96(6), 1553-1561. https://doi.org/10.2134/agronj2004.1553

QGIS. (2020). A free and open-source geographic information system. Retrieved from https://www.qgis.org/en/site/

R Core Team. (2020). R: A language and environment for statistical computing. Vienna, Austria: R Foundation for Statistical Computing. Retrieved from https://www.R-project.org/

Ramos, M. I., Gil, A. J., Feito, F. R., \& García-Ferrer, A. (2007). Using GPS and GIS tools to monitor olive tree movements. Comput. Electron. Agric., 57(2), 135-148. https://doi.org/10.1016/j.compag.2007.03.003

Seelan, S. K., Laguette, S., Casady, G. M., \& Seielstad, G. A. (2003). Remote sensing applications for precision agriculture: A learning community approach. Remote Sens. Environ., 88(1-2), 157-169. https://doi.org/10.1016/j.rse.2003.04.007

Stone, K., Bauer, P., O'Shaughnessy, S. A., Andrade, M. A., \& Evett, S. (2020). A variable-rate irrigation decision support system for corn in the U.S. eastern coastal plain. Trans. ASABE, 63(5), https://doi.org/10.13031/trans.13965, in press.

Sui, R., O'Shaughnessy, S. A., Evett, S. R., Andrade, M. A., \& Baggard, J. (2020). Evaluation of a decision support system for variable-rate irrigation in a humid region. Trans. ASABE, 63(5), https://doi.org/10.13031/trans.13904, in press.

Thorp, K. R., \& Bronson, K. F. (2013). A model-independent opensource geospatial tool for managing point-based environmental model simulations at multiple spatial locations. Environ. Model. Software, 50, 25-36. https://doi.org/10.1016/j.envsoft.2013.09.002

Tolk, J. A. (2003a). Soils, permanent wilting points. In B. A. Stewart \& T. A. Howell (Eds.), Encyclopedia of water science (pp. 927-929). New York, NY: Marcel Dekker.

Tolk, J. A. (2003b). Plant-available soil water. In B. A. Stewart \& T. A. Howell (Eds.), Encyclopedia of water science (pp. 669672). New York, NY: Marcel Dekker.

Tolk, J. A., Howell, T. A., \& Evett, S. R. (1998). Evapotranspiration and yield of corn grown on three High Plains soils. Agron. J., 90(4), 447-454. https://doi.org/10.2134/agronj1998.00021962009000040001x

Yazar, A., Howell, T. A., Dusek, D. A., \& Copeland, K. S. (1999). Evaluation of crop water stress index for LEPA irrigated corn. Irrig. Sci., 18(4), 171-180. https://doi.org/10.1007/s002710050059

Zhang, N., \& Taylor, R. K. (2001). Applications of a field-level geographic information system (FIS) in precision agriculture. Appl. Eng. Agric., 17(6), 885-892. https://doi.org/10.13031/2013.6829

Zhang, N., Runquist, E., Schrock, M., Havlin, J., Kluitenburg, G., \& Redulla, C. (1999). Making GIS a versatile analytical tool for research in precision farming. Comput. Electron. Agric., 22(2), 221-231. https://doi.org/10.1016/S0168-1699(99)00020-4

Zhao, J., Xue, Q., Jessup, K. E., Hao, B., Hou, X., Marek, T. H.,... Brauer, D. K. (2018). Yield and water use of drought-tolerant maize hybrids in a semiarid environment. Field Crops Res., 216, 1-9. https://doi.org/10.1016/j.fcr.2017.11.001 